\title{
FRENCH CRIMINAL PROCEDURE
}

A hearty contempt for things foreign, in general, and legal institutions, in particular, is probably a healthful sign of national youth and of buoyant, of exaggerated patriotism. Nations, like individuals, become more self-critical with age and less inclined to decry things merely on the ground that they are foreign. Whether the earlier is not the happier and stronger period I am not sure. We Americans, however, as we are so often reminded, are living in an epoch of rapid development. Increased facilities of communication, bringing us in closer contact with nations on the other side of the water, have tended to teach us that we do not monopolize all the virtue and all the wisdom upon this planet and that the English common law is not the ultimate acme of human sapiency, however much the revered Blackstone may have delighted in that pious thought.

The annexation of twelve millions of people living under the civil law has brought under the American flag institutions which we had formerly scarcely known, save by caricature. Nevertheless the youthful tendency is still strong in us and occasionally the national enthusiasm seems aroused in unreasonable fashion. It is but a few days since our press was thundering away at the monstrous medievalism of the French legal procedure, as instanced by the trial of a woman charged with the murder of her mother and husband. Yet I am convinced that the procedure in that sensational case with its picturesque background of murderers clad in Levitical garments did not in any essential particular deviate from the methods usually prevailing in the French Court of Assizes. As these have been the methods daily practiced in those courts since the time of Napoleon, and in substance at least some two hundred years further back, the impression of novelty made upon the American people by the reports of the Steinheil case seems somewhat surprising. Public interest may have been largely due to the fact that the prisoner at the bar was a woman whose qualities, physical and mental, were far above the average, and whose past career had been a subject for salacious gossip in high political circles.

Despite all this, however, there was one objective upon which the popular attack seems to have centered as the characteristic of the French system most repugnant to American ideas. The 
fact that this interesting woman was forced to take the witness stand and for several days was interrogated in mercilessly hectoring fashion by the presiding judge is, of course, a thing unknown to our common law procedure.

The popular instinct in thus seizing upon the point, which appeared to it so anomalous, hit upon the really fundamental distinction between the two great systems of criminal procedure which divide the civilized world-one a lineal descendant of the Imperial Roman procedure, the other purely English in its origin and development. In the domain of criminal law the world-wide antithesis is between the Roman or inquisitorial system and the English or controversial system.

Our American lawyers, taught by traditional piety to believe that habeas corpus was the palladium of our liberties, and that Rome and Carthage lost theirs only because they had not invented that admirable legal device, have been usually content to dismiss the inquisitorial system with a contemptuous shrug or a violent epithet. It must thus have been with some astonishment that many an American lawyer read the recent addresses and review articles of the Honorable William $\mathrm{H}$. Taft suggesting that there is much in our criminal procedure that may well have outlived its usefulness, and that some of the elements of the Latin procedure which he had found and studied in the Philippine Islands were not without advantage, including the interrogation of defendants in criminal cases. I dare say that the most conservative stickler for the common law would not hesitate to question the office boy whom he suspected of pilfering his desk or pockets and would assume this to be the most natural method of ascertaining the truth. Yet when society wishes to protect itself against crime this obvious method becomes unconstitutional and abhorrent.

In practice, nevertheless, the "Question" is supposed to be very generally used by the police of the larger cities for the purpose of detecting crime. Denunciation of the illegal character of what is popularly termed the "Third Degree" has been impotent to check it and this extra legal inquisitorial method is believed to prevail quite generally. Nor would one who has seen the police or magistrates' courts in operation in the cities, find it so diffcult to think himself in the presence of a French "Juge $d$ " Instruction." The law of overruling necessity seems to be making more and more in the direction of our employing the most obvious method of seeking the guilty. Bentham, referring to the 
old English rules of evidence, said "they were admirably adapted to the exclusion of the truth." Many lawyers practicing in the criminal courts are now beginning to believe that the rule which prevents the State from compelling a person charged with crime to testify may well fall within the same category. Officially, however, we are still wedded to the old theory. Recently in our Spanish possessions, Congress has, by statute, enacted the provisions of the Fifth Amendment, so that to-day a prisoner in those fortunate isles may no longer be compelled to be a witness against himself. I do not think sufficient data as yet available from which a judgment may be formed as to the expediency of this change in the criminal law, but it was one whose wisdom has been greatly doubted by President Taft. And we must, on the other hand, remember that for a long time in the United States, and recently in England, the strict rule against self-crimination has been generally relaxed by statute and a defendant, who so wishes, may now be allowed to testify in his own behalf. Doubtless this modification was intended to enable an innocent man, anxious for an opportunity to clear himself of crime, to go upon the witness stand. I am inclined to believe, however, that the unforseen, but inevitably logical, consequence must be to destroy the value (if any there be to-day) of the constitutional guarantee that no man shall be compelled to be a witness against himself. The statutes now provide, and judges must charge, that no presumption is to be derived from the failure of the prisoner to testify in his own behalf, yet juries will still be human, and even the legislature cannot always reverse the rules of human ratiocination.

This departure from the common law marks, to my mind, a long step toward bridging the chasm between the inquisitorial system and our own.

The leading features of English-American criminal law are its litigious or controversial nature and the institution of jury trial, about which its whole procedure grew up. Jury trial, however, has ceased to be a sacros sanct institution, and in several of our jurisdictions informations by the public prosecutor, have taken the place of indictment.by grand jury, and unanimity has made way for a majority verdict. As the continental nations have adopted the English jury as a body for trying the facts in important criminal cases, the fundamental remaining distinction between the two systems is this: In the French system the initiative in and conduct of criminal cases belongs wholly to the courts (C. C. 
I., Art. I); the procedure is not really in the nature of a lawsuit, but is rather an investigation conducted by the government officers for the purpose of detecting criminality. The English procedure, on the other hand, still smacks of its Germanic origin in retaining the character of an ordinary law suit, in which the plaintiff must prove his case against the defendant in practically the same manner as he must do in a civil case, with the additional burden that in the criminal case a plaintiff cannot put the defendant on the stand as he may now do in civil cases.

Popular prejudices usually have ancient origins. Surely, much of the popular dislike for compulsory examination of defendants is due to the association of the inquisitorial idea with that secret and awful tribunal which in the Middle Age sought to secure religious uniformity by the liberal application of the "Question." While it is true that neither the medieval nor the Spanish Inquisition originated the procedure there employed, which was derived from the Roman law, it nevertheless applied it in much more arbitrary fashion, and to the exaggeration of its defects added torture as a leading feature. Considered apart from methods, however, there is nothing repugnant to enlightened justice in a mere oral public examination of the defendant in a criminal case.

I cannot attempt to give here anything more than the roughest outline of the French procedure. The French criminal law is codified in admirably lucid and logical fashion in two codes-the Code of Criminal Instruction (Code d' Instruction Criminelle), and the Code Pénal, the first treating of the procedure in the criminal courts, and the second defining crimes and prescribing corresponding punishments. While both of these codes were enacted under the master hand that re-created and re-framed French institutions during the first ten years of the last century, yet nearly all their leading features antedate Napoleon.

The origin of the French criminal law goes back to the Roman law. The criminal law of the later Roman Republic and early Empire was like our own, controversial or litigious; the private party was plaintiff and the facts were submitted to a jury or commission, the Judex merely acting as a referee, and charging the law.

With the growth of Rome and the enormous influx of various peoples from all parts of the Mediterranean basin, there grew tip a considerable criminal class, more formidable perhaps than any we have yet developed in our own metropolitan slums. Probably 
owing to this, the methods of criminal procedure underwent a radical change. The City Pretor, charged with general police surveillance of the city, seems to have absorbed to himself during the first and second centuries all criminal jurisdiction, and the older methods were superseded by those in vogue in his courts. The procedure there was inquisitorial, the police authorities themselves initiating the proceedings and the judge deciding the whole case, both fact and law. This method, by which one judge sitting in secret, examined the defendant and witnesses at the instigation of the government was called "Inquisitio." It seems to have become more arbitrary as time went on. In the western portion of the Empire it was superseded by the customs of the Germanic tribes. The ordeal, compurgation, trial by battle, etc., took the place of a procedure, which, whatever its defects, was at least rational, that is to say, based upon an endeavor to ascertain the facts by methods of inquiry founded upon human reason.

With the growth of the French monarchy, the action of the French royal courts was extended and at the same time this rational procedure gradually superseded the Germanic procedure whose continued existence was rapidly becoming incompatible with growing civilization. In developing a procedure for the royal courts, the Crown naturally looked to the ecclesiastical courts where the Roman procedure still continued in force. This procedure was codified in an important ordinance in 1539 by Francis I, and again in a more complete and elaborate codification in the great ordinance of Louis XIV's famous minister, Colbert, of 1690 , which continued to be the basis of criminal procedure down to the time of the Revolution.

At the Revolution, laws were passed to wholly remodel French procedure, making it public, simplifying it and providing jury trial, as well as having citizens sit with the judges. The law was for a time in very uncertain condition until Napoleon undertook its comprehensive codification. He had little sympathy with the jury system so that his Code d' Instruction Criminelle (I809) was highly reactionary. It is true a jury was provided for, but it was merely superimposed upon the already existing structure and did not harmonize with it. Jury panels were taken from a very small class, and the expectations of the men of the Revolution that the procedure of the old regime would be wholly changed were completely frustrated. The legal habits of centuries cannot be permanently changed by revolution and the 
Code d' Instruction Criminelle is still very largely founded upon the ordinance of 1690 . This code has been subject to alteration from time to time, and was revised in 1834 , although the changes were not very material.

The Code of Criminal Instruction contains 643 paragraphs. This code defines the organization of the courts, their jurisdiction and the procedure to be followed therein. The first book is concerned with the "judicial police" (police judiciaire) and the officers who exercise such police, and contains only one title. The second book treats of the procedure in the criminal courts, and is composed of seven titles, respectively:

First-Tribunals of police.

Second-Matters which must be submitted to a jury.

Third-Methods of appeal.

Fourth-Procedure in certain special classes of cases.

Fifth-Removal of causes.

Sixth-Special courts.

Seventh-Certain matters of public interest and social safety.

The inquisitorial nature of the French procedure is indicated by the first article of the preliminary disposition of the code which provides that the right to initiate proceedings resulting in the infliction of punishments, belongs solely to the government officers to whom it is intrusted by law (C. C. I., Art. I). Where a crime is also a tort, the party injured may bring his action before the same tribunal as that which hears the criminal case (partie civile), and the two may be heard together. This is a proceeding which from the standpoint of economy and efficiency has much to recommend it.

There are three classes of infractions of criminal law. They are defined in the Penal Code (Art. I, et. seq.) as contraventions, delicts and crimes. Contraventions are petty offenses justiciable in the smaller magistrate or police courts, subjecting the culprit to small fines or a few days' imprisonment. Delicts are punished in the court called "Police Correctionel" and are subject to fines and a term of imprisonment not exceeding five years.

The body called the "Magistrature" differs from anything we have in this country in that it includes not only all the judges but also the body of public prosecutors. The procureurs (district attorneys) constitute a part of the Magistrature and are called "The Magistrature Debout (standing)." They have much wider powers than our district attorneys and exercise quasi-judicial 
functions. They are charged with the discovery and prosecution of crime, and they, with the Maires, Gardes Champetres (Rural Police), Juges de Paix, Officers of the Gendarmeric, Commissaires Generaux and Juges $d^{\prime}$ Instruction compose the police judiciary.

In each district there is a Juge d' Instruction, nominated for a period of three years by the President. Save in case of open breach of the peace, he does not himself initiate prosecutions but waits to receive complaints from the procureur.

The proceeding before the Judge of Instruction is probably the most characteristic portion of the French procedure. The prisoner is brought before the judge in his chamber and testifies, without the presence of the other witnesses. The hearings are secret, and until 1897 the prisoner was not entitled to counsel. By a law of that date, however, he now possesses the right to request to have such counsel as he may designate to represent him or in case of his failure to do so, counsel will be appointed by the court. Provision has also been made by the same law that he should be informed of the documentary evidence against him. The witnesses are sworn, interrogated and their answers reduced to writing. They are examined separately. Persons must be examined within twenty-four hours after they have been arrested, otherwise they will be considered as illegally detained. The Judge of Instruction may, and in some cases must, grant bail, but the code seems to leave the matter very largely to his discretion where the penalty for the crime charged is more than two years' imprisonment. (C. C. I., II3.) In practice, bail is rarely asked for or granted, owing chiefly to the fact that arrest is made only after the judge has examined into the case sufficiently to warrant such arrest.

The judge examines fully the prisoner and all the witnesses, and if he deems it advisable, visits the spot where the alleged crime was committed. He is given full power to search houses, papers, and general effects of suspected persons (perquisition). This is one of the most drastic provisions of the French code and most at variance with our legal ideas. Immunity from search and seizure as a general right is quite unknown in France. The code provides (Sect. 87): "That the Judge of Instruction may betake himself wherever his presence is required, and may even of his own initiative go to the domicile of the arrested party, to there make a search (perquisition) of the papers, effects and 
generally of all those articles which may be thought useful for the disclosure of the truth." Provision is also made that he may search in whatever other place he may believe evidenciary matter to be contained. If such papers or objects are without his arrondissement he may call upon the judge in whose arrondissement they are, to make examination. One cannot help contrasting this very broad power with the rulings of our courts under the Fourth Amendment to the Constitution. The elaborate reasoning in Adams v. New York, I92 U. S., 585, in which the Supreme Court held that incriminating articles, although unlawfully seized by the police, were not thereby made inadmissible as evidence, would probably cause a French lawyer to feel the same kind of bewildered interest which we do in studying the tribal customs of the Patagonians. The most natural thing that a French procureur and Judge d'Instruction would think of would be to search the place where the perpetration of crime was suspected for evidence.

Whether from the standpoint of social efficiency this system is not on the whole better than our own, I seriously question. In any event, I think that an examination of our decisions will show that we are restricting and limiting, rather than broadening the prohibition against searches and seizures which grew out of political conditions wholly different from our own, and which, strictly interpreted, renders it much easier for the criminal class to carry on their avocation. ${ }^{1}$

If, after the conclusion of the examination the Juge d' Instruction is of the opinion either that the facts adduced do not make out any crime or that there is not sufficient evidence against the person charged, he then decrees that there is no ground for prosecution (non lieu à poursuivre) and the prisoner is released. If, on the other hand, he finds that the criminal law has been violated, he must then decide whether such violation constitutes a contravention or a delict. If the former, he will send the record (dossier) to one of the minor police courts; if the latter, to the Tribunal Correctionel for trial there.

Should he, however, find that the act is of so serious a character as to constitute a felony (that is to say, a crime for which "peines afflictives ou infamantes" are the punishment), he sends the dossier (record) to the Procureur General at the Court of Appeal of the district in which the crime was committed.

1 Twining v. New Jersey, 2II U. S., 78, 103. 
This court is the regular body which hears all appeals in civil cases and also possesses criminal jurisdiction. One of the chambers or divisions of this court is called "La Chambre des Mises en Accusation." This subdivision of the Court of Appeals decides upon the dossier whether the prisoner shall be sent to the Court of Assizes. This chamber is really an indicting body. It may either concur with the Procureur and send the prisoner to be tried by jury, or it may decide that the case is one falling within the jurisdiction of one of the police tribunals. An appeal lies from the action of the Chamber.

If the Chamber holds that the crime is one to be tried at the Court of Assizes, the Procureur General then prepares the document called "Acte d"Accusation," corresponding somewhat to our own indictment. This "Acte d' Accusation" drawn up by the Procureur himself, contains a summary of all the evidence taken before the Juge d' Instruction. It is usually a somewhat long and denunciatory paper. The prisoner is then brought for trial before the Court of Assizes. The President of the Court of Assizes is taken from one of the judges of the Court of Appeals and has as assistant judges, two judges of the Court of First Instance, of the place where the Court of Assizes is sitting. In addition to the judges, there is a jury of twelve men drawn from a jury list. They are not held to the rule of unanimity, but decide by majority vote, the result being announced without dissent.

The trial is public. It opens by the appearance of the accused and his being asked by the President his name, age, etc. An interesting episode then occurs. Section 3 II of the Code provides that: "The President shall admonish counsel for the accused that he can say nothing contrary to his conscience or contrary to the respect due to the laws and that he must express himself with decorum and moderation." A provision of this kind inserted into our criminal codes might not be without good effect, nor without reason. The jury is then sworn, and the clerk reads the Acte d'Accusation. The Procureur opens the case and reads the list of witnesses who have been summoned, whether for the State, the accused, or for the civil plaintiff. The names of these witnesses must have been communicated by the party calling them to the other parties interested at least twenty-four hours before the first examination. While this restrictive list might prevent all the witnesses who had not testified before the Juge $d^{\prime}$ Instruction from appearing at the trial, provision is made 
(Sect. 269) by which the court may at any time of its own motion summon any witness whose testimony it deems material.

The accused is now examined. This examination usually takes a very wide range as his whole life history which has been thoroughly developed before the Juge d' Instruction is gone over by the President. There are no rules of relevancy and only a few of competency, such as that prohibiting persons closely related from testifying against each other. (C. C. I., 322.) Section 270 of the Code provicles that the President may prohibit all matter which may tend to prolong the discussion (debats), without furnishing any greater hope of certainty in the results. In the Steinheil case, the President began his interrogatory of Mme. Steinheil, which lasted over several days, by asking her as to some alleged elopement which had occurred twenty years before the date of the crime. The whole of the first day's hearing was taken up with her history, and was a long wrangle in which the witness was allowed to answer what, and as much as she pleased, and in which dialectic honors dicl not always remain with the President.

Cross-examination as such is unknown, and the witnesses are questioned by the President, although the Procureur General or members of the jury may, by obtaining permission of the President, ask questions. It is curiously enough specifically provided. (Sect. 39) that witnesses may not be interrupted. Opportunity is thus given a witness to tell his whole story to the jury which has perhaps some advantages over our method of categoric question and answer. The accused or his counsel may question him by the voice of the President (l' organe du President), when his deposition is concluded, and may say anything against him or against his testimony which he may think useful to the defense. The examination of witnesses having ended, the case is then presented to the jury. The Procureur General speaks first, anc the accused and his counsel have the last word. This is a very great advantage for the accused, which has been pretty generally overlooked in the sweeping criticisms made of the French law

The President is no longer allowed to sum up to the jury. Hi merely calls their attention to the functions which the law im poses upon them and he asks them to pass upon the questior whether the accused is guilty of having committed such and sucl crime, together with the circumstances included within the Act. d'Accusation. Sometimes the questions are very numerous; 
have known in a case at which I was present, the jury to be asked to pass upon twenty-four questions. General verdicts are unknown; all verdicts are special. The Court of Cassation has held that the President must put to the jury a distinct question as to every principal allegation of the accusation. (C. C. I., 337.) The jury is also called upon to pass upon the question as to whether there exist attenuating circumstances (circonstances attemuantes). This right or privilege upon the part of the jury has been much criticised in France as in cases of heinous and cold blooded crimes, a verdict of circonstances attenuates is often rendered. I attribute this, however, in great part to two circumstances. First, the growing dislike of the death penalty felt in France, and second, that as the verdict is by majority vote, it is often due to compromise. The "attenuation" is probably frequently found not in the crime, but in the evidence as to its commission. In this country, juries often seem to reach the same result by finding a lower degree of crime. There are so many circumstances attenuating guilt which the law cannot recognize or classify, I am inclined to think that the circonstances attenuates method is not on the whole a bad one. The questions of the President are written out and given to the jury, together with the Act of Accusation and the evidence. The jury is then informed that they are to decide the case, not according to any mechanical rules as to number of witnesses, but by asking themselves the question whether they have an intimate conviction as to the guilt or innocence of the prisoner. (Avez-vous une Intime Conviction.) (C. C. I., 342.) The verdict is then rendered by majority vote, but the number of votes cannot be declared under penalty of nullifying the judgment.

If the accused is found guilty and the court is convinced that although there are no errors of form, yet the jury have made a fundamental mistake, it has power to grant a new trial. It must be remembered that throughout the trial, the civil plaintiff is represented by his counsel and that the verdict also includes the question of whether the plaintiff has been damaged by the tort.

An elaborate system of appeal both to the Court of Appeals and the Court of Cessation exists. In addition, a revision or a new trial may be asked for, on the ground of newly discovered evidence, perjury of the witnesses or of another criminal judgment, inconsistent with the guilt of the defendant. (C. C. I., 443.) 
The jurisdiction over crimes whose punishment exceeds five days imprisonment and fifteen francs penalty is confided to the Police Correctionel Courts which are also the tribunals of first instance, having general civil jurisdiction. These tribunals are composed of three judges. (C. C. I., I79-180.) Their sessions are public and the procedure is similar to that of the Court of Assizes, minus the features peculiar to the jury. From these courts, appeal lies to the Court of Appeals. These latter courts have full jurisdiction virtually to retry the case and to enter any judgment they may think conformable to law and justice. They may, and often do, increase or diminish the penalty, or they may hold that the accused should have been held for the Assizes. This broad appellate jurisdiction is not unknown under the American flag, for in the Philippine Islands we have the same system, and the Supreme Court in a very recent interesting case, held that a prisoner was not placed twice in jeopardy within the meaning of the constitutional guarantee, because of the fact that upon his appeal his punishment had been greatly increased. (Trono v. U.S., I99 U. S., 52I.) Where there is no jury, as in the Correctionel Courts, this seems to be a wise and humane system. No reason exists in the absence of jury trial for not according such a broad power to the court on appeal.

A pretty general discussion of foreign criminal procedure would seem not inopportune in America at the present time. It is clear that certain features of the French procedure are entirely inimical to our ideas, but I am inclined to think that in final analysis, our objection is rather to the methods than to the fundamental principles. The essential feature of the inquisitorial system, namely, the examination of the party charged with crime is certainly based upon a sound, common-sense view. Whenever or wherever any kind of investigation is held, and real investigation is desired, the parties most cognizant of the transaction are examined. The rule as to incompetency of parties in civil cases has long since been abolished. I find it difficult to see why the old rule should be retained in criminal cases. It grew up in a time when examination of the parties meant interrogation accompanied by the application of various ingenious devices for the purpases of extorting confession by producing the maximum of physical pain. That a morally developing society should finally revolt against this hideous barbarism by abolishing "the question," was quite natural. 
As Stevens, the historian of the English criminal law has said: "In the seventeenth century the accepted maxim which was sometimes called the Law of God, and sometimes the Common Law of England, the common right was 'nemo tenetur accusarc se ipsum.' A phrase not the less influential because it rested on no definite authority." Of course, the self-accusation there mentioned was that which was produced by torture, a thing unknown to the Roman law in its better days, and in no wise necessarily connected with the examination of the prisoner. The medieval theory seems to have been that the only complete proof of the commission of crime was the confession of the culprit and that such confession, however superinduced, was the necessary basis for conviction. It was only in the eighteenth century in England that the practice of questioning a defendant on his trial was entirely done away with.

As the rule stands in common law countries to-day, it appears to me to give the guilty an unfair advantage. That the privilege of testifying may be, and usually is of assistance to the innocent is evident from the fact that the prohibition against the witness appearing in his own behalf has been removed.

I do not mean, however, to wholly approve the French methods. It is one thing to have a party after he has been fully apprised of the nature of the crimes charged, and the evidence against him, put upon the witness stand and examined by the prosecutor, with an opportunity for a re-examination by his counsel, and quite another to have him brought before a magistrate, questioned at the discretion of that magistrate and then again questioned at his trial by the president of the tribunal. This latter proceeding certainly lacks the dignity which makes of the judge an impartial arbiter, and must often work great injustice in the case of a sensitive or timid defendant. Much criticism has been excited in France of recent years by the practice which permits the president to conduct the examinations during the trial. Some French lawyers believe this to be contrary to the law, but the provision of the code (3I9) wotld seem to indicate that all questions must be addressed by the voice of the president (par l'organe du President). It is stated that the Ministry of Justice is now to ask for an amendment of the criminal code by which the president will be relieved of this duty, and questions will be asked by both prosecution and defense. This would, it seems to me, have a wider effect than to merely impose 
this function upon counsel. It might well lead, I think, in time to the development of cross-examination, a thing hitherto unknown to the French law, and which is certainly, within reasonable limits, a very valuable device for the sifting of testimony.

Whether the French system as a whole is more efficient in the repression of crime, than our own, I do not know, and I doubt whether the question can be answered positively. It is an outgrowth of French society and conforms to French needs and views. With slight modification such as is now recommended, I see nothing in it incompatible with a perfectly just and efficient administration of the criminal law. It has long been a maxim of the English criminal law that it were better that ninety-nine guilty men should escape than one innocent man should suffer. Whether this is sound from the social standpoint, may be greatly doubted, but certain it is that a criminal law so framed and administered as to allow the escape of ninety-nine per cent or any considerable percentage of criminals, is an inefficient safeguard for modern society. That the delays and technicalities of the criminal law have become in America a shocking abuse is manifest and admitted. The appalling prominence of "Judge Lynch" cannot be dismissed with a mere phrase as to American lawlessness, but the paralysis of legal procedure due to over emphasis of individual rights, as opposed to the collective good, must be held largely responsible.

However unfortunate or undignified we may have considered the hectoring tone of the presiding judge who questioned Mrs. Steinheil, she was acquitted. Doubtless too great partisanship on the part of the court often influences a French jury in favor of the prisoner. While this is another unfortunate corollary of the fact that the interrogatory is carried on by the court rather than by counsel, it nevertheless greatly weakens the criticism that such methods railroad the defendant.

Undoubtedly the jury system, the public nature of all trials and examinations of prisoners, and the litigious as distinguished from the inquisitorial method of procedure are valuable acquisitions which American law should not lightly surrender. It verges. however, upon the absurd to turn respect for old rules or maxims into mere fetish worship. The rule against compelling examination of parties in criminal cases may well be thought to have outlived its usefulness. It is of no value to the innocent, and highly detrimental to society in its war against crime. Must we 
continue to maintain it because some hundreds of years ago its violation was accompanied with incidents which have disappeared as completely as have trial by battle, or the ordeal of walking upon red hot iron as a satisfactory test for the ascertainment of criminality?

If the French legislator has been wise and liberal enough to borrow our jury system, may we not in turn gain something by examining in sympathetic spirit a system which has been worked out by the best minds of continental Europe?

Increase in crimes of violence, epidemics of commercial fraud and general disregard for law are appallingly prevalent in nearly all parts of our Union. That our criminal law, both in its substance and in its administration, is in unsatisfactory condition is manifest. In striving toward its needed reform, we cannot wisely ignore the advantages, nor overlook the faults of other legal systems prevailing among peoples of a civilization as highly developed as our own.

New York City.

Frederic R. Coudert. 